Удк 37

ЗАХАРЕВИЧ Владлена Алексеевна, аспирант кафедры дошкольной педагогики

ПЕДАГОГИЧЕСКИЕ УСЛОВИЯ
ФОРМИРОВАНИЯ СОЦИАЛЬНЫХ
КОМПЕТЕНЦИЙ СТУДЕНТОВ
БАКАЛАВРИАТА В ПРОЦЕССЕ
ПЕДАГОГИЧЕСКОЙ ПРАКТИКИ

В данной статье автор рассматривает педагогические условия формирования у студентов бакалавриата социальных компетенций в процессе педагогической практики. Автор раскрывает понятие «компетентность», а также излагает методику и выводы по проведенному исследованию, направленному на выявление роли педагогической практики в формировании социальных компетенций студентов бакалавриата.

Ключевые слова: компетенция, студент, практика, педагогическая практика, бакалавриат, педагогика.
ZAKHAREVICH Vladlena Alekseevna, Graduate Student of Chair of Preschool Pedagogy

\section{PEDAGOGICAL CONDITIONS FOR THE FORMATION OF SOCIAL COMPETENCES OF UNDERGRADUATE STUDENTS DURING THEIR TEACHING PRACTICE}

The author of the article considers the pedagogical conditions for the formation of social competences of undergraduate students in their teaching practice. The author highlights the concept of "competence", as well as presents the methodology and conclusions of a study aimed at identifying the role of teaching practice in the formation of social competences of undergraduate students.

Keywords: competence, student, practice, teaching practice, bachelor, pedagogy.

Федеральная целевая программа развития образования на 2011-2015 годы, Стратегия инновационного развития России на период до 2020 г., Федеральный Закон «Об образовании в Российской Федерации», «Стратегия модернизации содержания общего образования», Концепция поддержки педагогического образования, Профессионального стандарта педагога, ФГОС ДО, ФГОСЗ+ предусматривают модернизацию приоритетных направлений развития высшего педагогического образования, согласно которым кардинально меняется общая его идеология, совпадающая с идеологией мирового сообщества в этой сфере.

Содержание высшего педагогического образования, предусматривающее подготовку бакалавров по направлению «Педагогическое образование», конкретизируется в профиле «Дошкольное образование», обеспечивает пространство развития личности выпускника нового типа, активного, высококвалифицированного члена общества, социально адаптивного в меняющихся условиях, способного к саморазвитию и творчеству.

В связи с этим особое значение приобретает проблема использования компетентностного подхода в формировании профессиональных и социальных компетенций будущего педагога.

Компетентностный подход в совокупности с модульным, событийным и деятельностным подходами ориентирует систему подготовки бакалавров на формирование профессиональных и личностных компетенций бакалавра, интеллектуальных, универсальных, практических навыков и умений, обеспечивающих освоение трудовых функций: понимание социальной значимости будущей педагогической деятельности, умение работать в команде профессионалов, взаимодействовать со взрослыми и детьми, руководить коллективом детей и организовывать процесс обучения, воспитания и развития ребенка, навыки нестандартного мышления и принятия ответственного решения. Актуализация вопроса формирования социальной компетенции в процессе подготовки бакалавров связана с характером деятельности будущего педагога - сотрудничество, общение, взаимодействие с субъектами (дети, педагоги, родители) на личностном, бытовом, профессиональном уровнях.

Опираясь на данные теоретического анализа научных исследований проблем модернизации высшего образования, мы сделали акцент на изучение вопроса формирования социальных компетенций бакалавров педагогики в процессе педагогической практики. В нашем исследовании педагогическая практика в дошкольных образовательных организациях рассматривается как среда формирования социальных компетенций студентов.

Наше исследование направлено на решение этих противоречий.

В современной педагогической науке существуют разные подходы к определению содержания компетентностей. Остановим наше внимание на тех из них, которые служат основанием для фрормирования научного аппарата нашего исследования. И.А. Зимняя трактует «компетентность» как основывающийся на знаниях интеллектуально и личностно обусловленный опыт социально-профессиональной жизнедеятельности человека [2]. А.В. Хуторской с позиций синергетического подхода определяет компетентность как совокупность смысловых ЗУНов, способствующих и необходимых для осуществления личностной и социально-значимой продуктивной деятельности, позволяющих субъекту приспособиться к изменению условий жизни [10]. 
ISSN 2219-6048 Историческая и социально-образовательная мысль. Том 6 №6, Часть 2, 2014 Historical and social educational idea's Tom 6 \#6, Part 2, 2014

В динамических социально-профессиональных условиях становится востребованной не только образованность (компетентность), но и способность специалиста реализовать ее в практической деятельности (компетенция). Обращаясь к проблеме многообразия рассматриваемой дефиниции, мы принимаем определение, предложенное И.А. Зимней, а также европейским проектом TUNING: «Компетенции - это некоторые внутренние потенциальные, скрытые психологические новообразования (знания, представления, программы действий, системы ценностей и отношений), которые затем выявляются в компетентностях человека как актуальных деятельностных проявлениях» [3].

Логика нашего исследования побуждает к изучению сущностной характеристики социальной компетенции, выявлению ее составляющих, анализу классификаций этого типа компетенций. И.А. Зимняя определяет социально-профессиональную компетенцию как целостное личностное качество, проявляющееся в действиях, деятельности и поведении человека, выделяет четыре компонента этой компетенции: базовый (интеллектуальное обеспечение); личностный (ответственность, организованность, целеустремленность); социальный; профеессиональный. Основываясь на этих положениях, в ходе нашего исследования было сформулировано авторское понятие «социальные компетенции» применительно к выпускнику бакалавриата по профилю «Дошкольное образование». «Социальная компетенция понимается как профессиональная и личностная характеристика педагога, включающая совокупность теоретических (социальных, педагогических и психологических) представлений, знаний, интеллектуальных, универсальных, практических умений и навыков общения, взаимодействия с детьми, родителями, педагогами, способствующая осуществлению трудовых функций соответственно требованиям Профессионального стандарта педагога, необходимых для эффективного решения целей и задач ФГОС дошкольного образования и в аспекте социализации детей раннего и дошкольного возраста». Рабочее определение исследуемого понятия позволило выделить четыре критерия: когнитивный, мотивационный, социально-перцептивный, профессиональный, которые представлены показателями: знание, понимание, интеллектуальные и практические навыки, универсальные умения.

Модернизация высшего образования в рамках компетентностного подхода коснулась не только содержания педагогического образования, но и фрорм организации и проведения педагогической практики как среды формирования социальных компетенций бакалавров и опыта коммуникаций в детском, родительском и профессиональном сообществах. В исследовании С.М. Дзидзоевой педагогическая практика в системе муниципального образования рассматривается в аспекте развития исследовательских компетенций студентов бакалавриата [1]. Она научно обосновывает необходимость модернизации педагогической практики в дОУ, определяет исследовательскую деятельность как индивидуальную траекторию научной самореализации и освоения студентами исследовательских компетенций.

Итоги научно-теоретического этапа исследования позволили выявить сущность компетентностного подхода в образовании, компетенций и компетентности, охарактеризовать социальную компетенцию как ведущую, ключевую и выявить роль педагогической практики в ее формировании. Анализ научной и методической литературы дает основание считать выбранную проблему исследования актуальной для теории и практики высшего педагогического образования, что определяет содержание экспериментальной работы в этом направлении.

Изложим ее основные положения. Педагогический эксперимент проводился по трем этапам. Констатирующий этап ставил целью определить первоначальный уровень социальных компетенций у студентов бакалавриата до начала эксперимента.

На констатирующем этапе были разработаны критерии и показатели социальных компетенций. Каждый критерий отражал спектр определенных трудовых функций, выполняемых педагогом ДОО. Проведен сравнительный анализ нормативных документов, предъявляющих требования к системе высшего педагогического образования и дошкольного образования и авторских подходов к сущности критериев и показателей социальной компетенции с позиций компетентностного и деятельностного подходов. С помощью ряда диагностических методик изучался фактический уровень сформированности у студентов бакалавриата социальных компетенций. Для достоверности полученных первоначальных данных проанализированы также программы учебных и производственных (педагогических) видов практики, разработанные кафедрой дошкольной педагогики ЮФУ с позиций представленности в них социального аспекта деятельности студента.

Полученные данные по изучению исходного уровня социальных компетенций у студентов бакалавриата с помощью собственной рефлексии и диагностических методик показали довольно низкий ее уровень у студентов, а также их слабое осознание роли социальной компе- 
тенции как ведущей в профессиональной деятельности педагога дошкольных образовательных организаций.

Анализ программ практики позволил сделать вывод о том, что ее содержание недостаточно, на наш взгляд, актуализирует ценностно-смысловые аспекты социальной компетенции, не представляется возможности для включения студентов бакалавриата в различные виды деятельности, связанные с организацией взаимодействий с детьми, родителями, педагогами.

Полученные данные на констатирующем этапе исследования обусловили необходимость определения научно-методических подходов к разработке модели фрормирования социальных компетенций как в процессе изучения теоретических дисциплин, так и в процессе различных видов практики, что было сделано на формирующем этапе.

Цель фрормирующего этапа эксперимента состояла в разработке и апробации педагогических условий развития социальных компетенций бакалавра в процессе педагогической практики.

Для этого спроектирована и апробирована социально-педагогическая модель практики как среды развития социальных компетенций студентов бакалавриата. Модель представлена: научно-теоретическим блоком; содержательно-целевым блоком; технологическим блоком; критериально-диагностическим блоком; результативно-оценочным блоком.

Были разработаны содержание и технологии деятельности студентов бакалавриата в детском, родительском и профессиональном сообществе.

Формирующий этап педагогического эксперимента подтвердил возможность переноса разработанных модулей в иные виды практик, доказал эффективность разработанных видов и методов деятельности студентов в различных социальных сообществах - детском, профессиональном, родительском, что привело к успешным результатам в освоении социальных компетенций. Таким образом, формирующий этап эксперимента, на котором осуществлялась апробация и внедрение социально-педагогической модели формирования социальных компетенций студентов в период профессиональной подготовки по направлению «Педагогическое образование», профиль «Дошкольное образование» на учебных и педагогических видах практики, позволил выявить динамику их становления и эффективные педагогические условия, обеспечивающие результативность в достижении поставленных целей. Формирующий этап эксперимента позволил охарактеризовать специфику становления критериев и показателей социальных компетенций студентов-бакалавров, выступивших основой фоомирования трудовых функций педагога, отраженных в Профрессиональном стандарте педагога: от воспроизведения знаний и элементарных умений до проектирования стратегии поведения в процессе взаимодействия и творческого решения проблем воспитания дошкольников; в когнитивном критерии - от понимания значимости коммуникаций в успешной профессиональной деятельности до профессионального опыта, практических умений вести дискуссию, проявлять толерантность к иному мнению, предупреждать социальные конфликты.

Контрольный этап эксперимента подтвердил эффеективность разработанных нами моделей процесса формирования социальных компетенций студентов бакалавриата. Сравнивая динамику становления каждого критерия социальных компетенций у бакалавров 2-го и 3-го курсов, сорормированных в процессе учебных и педагогических видов практики, отмечаем следующее:

- когнитивный критерий формировался от теоретического познания значимости и необходимости освоения социальных компетенций до самостоятельных достижений успехов в организации взаимодействий в детском, профессиональном, родительском сообществах;

- становление мотивационного критерия осуществлялось от мотиваций вступать в коммуникативную деятельность до поддержки баланса «близость-дистанция» в различных ситуациях взаимодействия для обеспечения эффективности педагогической деятельности;

- социально-перцептивный критерий формировался от адекватного восприятия собственных интеллектуальных, универсальных умений до практических навыков брать на себя ответственность за результаты взаимодействия и адекватные решения;

- становление профессионального критерия осуществлялось от интеллектуальных умений проектировать соотношения и соответствия между целью и результатом взаимодействия до практических навыков предупреждать конфликты в ситуациях общения, создавать комфортную и безопасную среду жизнедеятельности участников образовательного процесса, обеспечивать условия для самореализации в профессиональном сообществе.

Проведенный эксперимент позволил сделать вывод о том, что учебные и педагогические виды практик являются оптимальной и эффективной средой развития социальных компетенций студентов-бакалавров, поскольку они создают условия для активной позиции студентов осваивать компетенции, трудовые функции и практические навыки, усиливают мотивацию для 
ISSN 2219-6048 Историческая и социально-образовательная мысль. Том 6 №6, Часть 2, 2014 Historical and social educational idea's Tom 6 \#6, Part 2, 2014

самостоятельного познания научно-теоретических знаний в области профессиональных компетенций, обеспечивают возможность рефлексировать применяемые технологии в организации взаимодействий в детском, родительском, профессиональном сообществе и уровень проявленных социальных компетенций относительно требованиям ФГОС 3+, Профессионального стандарта педагога.

Контрольный этап эксперимента выявил существенные изменения по всем критериям социальных компетенций, заключающиеся в более высоких показателях по сравнению с исходными данными, полученными на констатирующим этапе. Данная экспериментальная работа открывает новые возможности проведения исследования в дальнейших направлениях: развитие социальных компетенций бакалавров в педагогических и производственных видах практики, разработка новых профессионально-педагогических модулей, осуществление пролонгированного исследования развития социальных компетенций не только в психолого-педагогических, но гуманитарных циклах дисциплин.

\section{БИБЛИОГРАФИЧЕСКИЕ ССЫЛКИ}

1. Дзидзоева С.М. Педагогическая практика как условие развития исследовательских компетенций студентов: дис. ... канд. пед. наук: 13.00.08 / Дзидзоева София Муратовна. - Ростов-на-Дону, 2009. - 148 с.

2. Зимняя И.А. Ключевые компетенции - новая парадигма результатов образования [Текст] / И.А. Зимняя //Высшее образование сегодня. - 2003. - № 5. - С. 6.

3. Настройка образовательных структур в Европе. Вклад университетов в Болонский процесс / координаторы X. Гонсалес, Р. Вагенаар, И. Вандермеер, П. Бенейтоне. TUNING Educational Structures in Europe TUNING [Электронный ресурc] URL:- http: //tuning. unideusto.org/tuningdeu,www.rug. nl /let/ tuningeu.

4. Хуторской А.В. Ключевые компоненты и образовательные стандарты [Электронный ресурс] / А.В. Хуторской; Доклад на отдел. философии образования и теории педагогики РАО 23 апреля 2002 г. Центр «Эйдос» - Pежим доступа: www. eidos .ru / news / compet. Html, свободный.

\section{Информация об авторе}

Захаревич Владлена Алексеевна, аспирант кафедры дошкольной педагогики Южного Федерального Университета,

Ростов - на - Дону, Россия

vladazc@yandex.ru

Получена: 19.12 .2014

\section{Information about the author}

Zakharevich Vladlena Alekseevna, Graduate Student of Chair for Preschool Pedagogy, Southern Federal University

Rostov - on - Donu city, Russia vladazc@yandex.ru

Received: 19.12.2014 